\title{
Arhodomonas aquaeolei gen. nov., sp. nov., an Aerobic, Halophilic Bacterium Isolated from a Subterranean Brine
}

\author{
JON P. ADKINS, ${ }^{1}$ MICHAEL T. MADIGAN, ${ }^{2}$ LINDA MANDELCO,${ }^{3}$ \\ CARL R. WOESE, ${ }^{3}$ AND RALPH S. TANNER ${ }^{1 *}$ \\ Department of Botany and Microbiology, University of Oklahoma, Norman, Oklahoma 73019'; \\ Department of Microbiology, Southern Illinois University, Carbondale, Illinois 62901 ${ }^{2}$; and \\ Department of Microbiology, University of Illinois, Urbana, Illinois $61801^{3}$
}

\begin{abstract}
Arhodomonas aquaeolei gen. nov., sp. nov., isolated from a petroleum reservoir production fluid, is described. The single isolate was an obligately halophilic, aerobic, gram-negative, oval rod-shaped bacterium that was actively motile by means of a single polar flagellum. It was catalase and oxidase positive. The isolate had a specific requirement for $\mathrm{NaCl}$; growth occurred at $\mathrm{NaCl}$ concentrations between 6 and $20 \%$, and optimal growth occurred in the presence of $15 \% \mathrm{NaCl}$. This species metabolized primarily organic acids and required biotin for growth. The name Arhodomonas is proposed for the new genus, which was placed in the gamma subclass of the Proteobacteria on the basis of the results of a $16 S$ rRNA sequence analysis. Although $A$. aquaeolei is most closely related to purple sulfur bacteria (the genera Ectothiorhodospira and Chromatium), it is not a phototrophic microorganism, which is consistent with its isolation from a subterranean environment. The major components of its cellular fatty acids were $C_{16: 0}, C_{18: 1}, C_{19: 0}, C_{16: 1}$, and $C_{18: 0}$ acids. The DNA base composition of the type strain is 67 mol\% G+C. The type and only strain is strain HA-1 (= ATCC 49307).
\end{abstract}

Halophiles are microorganisms which require high concentrations of $\mathrm{NaCl}$ for optimal growth and utilize various active processes of haloadaption to cope with the osmotic stress of concentrated salt solutions $(35,45)$. Halophiles have been isolated from various natural and man-made saline environments, including salterns (5), hypersaline lakes (10), saline soils (32), seawater (27), and petroleum reservoir production fluids $(1,6)$. Halophiles can be classified as halotolerant, moderately halophilic, or extremely halophilic, according to the concentration of $\mathrm{NaCl}$ required for optimal growth (20). Moderately halophilic microorganisms grow optimally at $\mathrm{NaCl}$ concentrations between 0.5 and $2.5 \mathrm{M}$, and this group includes a taxonomically and physiologically diverse array of bacteria.

An obligately halophilic, gram-negative, heterotrophic, aerobic, rod-shaped organism was isolated from an oil field brine. The phenotypic and phylogenetic characteristics of this organism were significantly different from the characteristics of all previously described halophiles and justify its designation as a new genus and new species. We describe the new genus Arhodomonas for this non-red-cell organism related to the purple sulfur bacteria. The type species is Arhodomonas aquaeolei, which was isolated from an oil field brine. The type strain is strain HA-1 (= ATCC 49307).

(A portion of this work has appeared previously [2]).

\section{MATERIALS AND METHODS}

Bacterial isolation. An obligately halophilic, aerobic, rodshaped eubacterium was isolated by Woody Jenkins from a petroleum reservoir production fluid (native produced water) obtained from a producing well in the Southeast Vassar Vertz Sand Unit in Payne County, Okla. (19). Produced brine samples were streaked onto solid medium containing $8.5 \mathrm{~g}$ of plate count broth (Difco Laboratories, Detroit, Mich.) per liter, $2 \%$ agar, and $10 \% \mathrm{NaCl}$ and incubated

\footnotetext{
* Corresponding author.
}

aerobically at $37^{\circ} \mathrm{C}$. A single isolate, designated strain $\mathrm{HA}-1^{\mathrm{T}}$ ( $\mathrm{T}=$ type strain), was recovered from these aerobic plates.

Media and cultivation methods. The basal medium contained the following components (per liter): $150 \mathrm{~g}$ of $\mathrm{NaCl}$, $1.0 \mathrm{~g}$ of $\mathrm{NH}_{4} \mathrm{Cl}, 0.1 \mathrm{~g}$ of $\mathrm{KCl}, 0.1 \mathrm{~g}$ of $\mathrm{KH}_{2} \mathrm{PO}_{4}, 0.2 \mathrm{~g}$ of $\mathrm{MgSO}_{4} \cdot 7 \mathrm{H}_{2} \mathrm{O}, 0.04 \mathrm{~g}$ of $\mathrm{CaCl}_{2} \cdot 2 \mathrm{H}_{2} \mathrm{O}, 10 \mathrm{~g}$ of TES buffer [ $N$-tris(hydroxymethyl)methyl-2-aminoethanesulfonic acid], $5 \mathrm{ml}$ of a trace metal solution (39), and $10 \mathrm{ml}$ of a vitamin solution (39). The $\mathrm{pH}$ of the medium was 7.0 to 7.3. A complex medium contained the following components (per liter): $150 \mathrm{~g}$ of $\mathrm{NaCl}, 17 \mathrm{~g}$ of plate count broth (Difco), and 2 $\mathrm{g}$ of $\mathrm{KNO}_{3}$. The pH was adjusted to 7.2. Solid media were prepared by adding $20 \mathrm{~g}$ of purified agar (BBL, Cockeysville, Md.) per liter. Incubation was at $37^{\circ} \mathrm{C}$. Anaerobic growth was tested in media prepared and inoculated by a strictly anaerobic technique $(3,4)$ in aluminum-sealed anaerobic culture tubes (catalog no. 2048-18150; Bellco Glass, Inc., Vineland, N.J.).

Nutritional and growth characteristics. The temperature range for growth was determined on a solid complex medium incubated at 5 to $45^{\circ} \mathrm{C}$; growth was scored visually. The $\mathrm{pH}$ range for growth was determined in complex broth medium whose final $\mathrm{pH}$ was adjusted to 5.0 to 9.0 with $\mathrm{HCl}$ or $\mathrm{KOH}$; growth was scored visually.

For the nutritional tests, a filter-sterilized substrate was added to the basal medium at a concentration of $0.1 \%$. Carbohydrates were used at a concentration of $0.2 \%$ (wt) vol). When amino acids were tested as sole carbon, nitrogen, and energy sources, $\mathrm{NH}_{4} \mathrm{Cl}$ and $\mathrm{KNO}_{3}$ were omitted from the basal medium. Growth was scored visually with reference to a negative control tube containing basal medium with no added organic compound. Positive results were scored after at least three consecutive transfers in the same medium. The nitrogen requirement was tested in basal medium containing acetate from which $\mathrm{NH}_{4} \mathrm{Cl}$ and $\mathrm{KNO}_{3}$ were omitted. The compounds tested were $\mathrm{NH}_{4} \mathrm{Cl}, \mathrm{KNO}_{3}$, tryptone, and L-amino acids.

To determine vitamin requirements, basal medium was prepared as described above except that the vitamin solution 
was not added. Individual vitamins were added from filtersterilized solutions.

Phototrophic growth medium contained the following components (per liter): $150 \mathrm{~g}$ of $\mathrm{NaCl}, 2 \mathrm{~g}$ of $\mathrm{KNO}_{3}, 0.5 \mathrm{~g}$ of $\mathrm{NH}_{4} \mathrm{Cl}, 0.3 \mathrm{~g}$ of $\mathrm{KCl}, 0.3 \mathrm{~g}$ of $\mathrm{KH}_{2} \mathrm{PO}_{4}, 0.5 \mathrm{~g}$ of $\mathrm{MgSO}_{4}$. $7 \mathrm{H}_{2} \mathrm{O}, 0.2 \mathrm{~g}$ of $\mathrm{CaCl}_{2} \cdot 2 \mathrm{H}_{2} \mathrm{O}, 1 \mathrm{~g}$ of yeast extract, $10 \mathrm{~g}$ of TES buffer, $5 \mathrm{ml}$ of a trace metal solution (39), and $20 \mathrm{ml}$ of a vitamin solution (39). After autoclaving, the medium was supplemented with $1.5 \mathrm{~g}$ of $\mathrm{NaHCO}_{3}$ per liter; the $\mathrm{NaHCO}_{3}$ was added from a freshly prepared, $\mathrm{CO}_{2}$-saturated, filtersterilized solution. Sodium sulfide and sodium thiosulfate were added from freshly prepared filter-sterilized solutions to final concentrations of 1 and $5 \mathrm{mM}$, respectively, to test for photoautotrophic growth with sulfide or thiosulfate as the electron donor. The final $\mathrm{pH}$ values of the media were 7.0 to 7.3. Photoheterotrophic growth was tested in medium containing $2 \mathrm{~g}$ of sodium acetate per liter. Phototrophic media were prepared aerobically and anaerobically. Cultures were incubated at $37^{\circ} \mathrm{C}$ with and without incandescent light. Growth was scored visually and compared with the growth of a positive control culture grown aerobically in medium containing acetate.

Ion specificity determination. Other salts were substituted for $\mathrm{NaCl}$ at concentrations of $1.5,2.0$, and $2.6 \mathrm{M}$ in basal medium containing $12 \mathrm{mM}$ acetate to examine the isolate's requirement for $\mathrm{NaCl}$. $\mathrm{KCl}, \mathrm{LiCl}, \mathrm{MgCl}_{2} \cdot 2 \mathrm{H}_{2} \mathrm{O}$, and $\mathrm{NH}_{4} \mathrm{Cl}$ were used to test for a specific $\mathrm{Na}^{+}$requirement. $\mathrm{A} \mathrm{Cl}^{-}$ requirement was examined by using $\mathrm{NaBr}, \mathrm{NaNO}_{3}, \mathrm{NaSO}_{4}$, and $\mathrm{Na}_{2} \mathrm{~S}_{2} \mathrm{O}_{3}$. Growth was scored visually and compared with the growth of a positive control in medium containing $\mathrm{NaCl}$.

Phenotypic characterization. The isolate was tested for general phenotypic characteristics by using previously described procedures $(34,37,43)$. Unless otherwise indicated, the tests were carried out in media containing $15 \% \mathrm{NaCl}$ at $\mathrm{pH} 7.0$ to 7.3 and the test preparations were incubated at $37^{\circ} \mathrm{C}$.

Antibiotic susceptibility was tested by spreading bacterial suspensions on plates containing complex medium and applying the following antibiotic discs (Difco): ampicillin (10 $\mu \mathrm{g})$, carbenicillin $(100 \mu \mathrm{g})$, chloramphenicol $(30 \mu \mathrm{g})$, erythromycin $(15 \mu \mathrm{g})$, gentamicin $(10 \mu \mathrm{g})$, neomycin $(30 \mu \mathrm{g})$, penicillin $\mathrm{G}(10 \mathrm{U})$, streptomycin $(10 \mu \mathrm{g})$, tetracycline $(30$ $\mu \mathrm{g})$, and vancomycin $(30 \mu \mathrm{g})$. Zones of inhibition were measured, and susceptibility was determined by comparison with standard inhibition zones (Difco).

Microscopy. Cellular morphology was determined by phase-contrast microscopy and electron microscopy. Micrographs were prepared from log-phase cells grown on a complex medium. For transmission electron microscopy, cells were spread onto carbon-coated Formvar grids, fixed with $1 \%$ glutaraldehyde in $15 \% \mathrm{NaCl}$, and negatively stained with $1 \%$ phosphotungstic acid (pH 7). Micrographs were taken with a Zeiss model EM-10 transmission electron microscope.

Cell membrane fatty acid analysis. A cell membrane fatty acid analysis was performed by Microcheck, Inc., Northfield, Vt. Whole-cell fatty acids were analyzed as fatty acid methyl esters by gas chromatography with a MIDI microbial identification system (MIDI, Inc., Newark, Del.). Fatty acid methyl ester extracts were prepared and chromatographed by using previously described methods $(24,25,36)$. The cells used for analysis were harvested from a culture grown for 72 $h$ at $37^{\circ} \mathrm{C}$ on tryptic soy broth agar (Difco) supplemented with $15 \% \mathrm{NaCl}$ and $0.2 \% \mathrm{KNO}_{3}$.

Determination of DNA base composition. The DNA was extracted and purified by the method of Marmur (22). The guanine-plus-cytosine $(\mathrm{G}+\mathrm{C})$ content of the DNA was determined from the midpoint value of the thermal denaturation profile (23) obtained with a Beckman model DU-8B spectrophotometer. The $\mathrm{G}+\mathrm{C}$ content of reference DNA from Escherichia coli b strain ATCC 11303 is $51 \mathrm{~mol} \%$.

16S rRNA sequence analysis. Arhodomonas aquaeolei HA-1 ${ }^{\mathrm{T}}\left(=\right.$ ATCC $\left.49307^{\mathrm{T}}\right)$ was grown on complex medium as described above. The 16S rRNAs from Arhodomonas aquaeolei, Ectothiorhodospira halophila SL1 (= DSM 244), Ectothiorhodospira halochloris ATCC 35916, Chromatium vinosum ATCC 17899, Pseudomonas aeruginosa ATCC 25330, and Oceanospirillum linum ATCC 11336 were sequenced by using methods described previously $(21,30)$. The sequences for Proteus vulgaris, Escherichia coli, and Agrobacterium tumefaciens DSM 30150 have been published previously $(7,26,49)$. Sequences were analyzed by a distance matrix analysis, using a program for fitting trees to distance data adapted by workers in the laboratory of Carl $R$. Woese $(8,17,30)$.

Nucleotide sequence accession numbers. The 16S rRNA sequences of Arhodomonas aquaeolei, Ectothiorhodospira halophila SL1, Ectothiorhodospira halochloris ATCC 35916, Chromatium vinosum ATCC 17899, Pseudomonas aeruginosa ATCC 25330, and $O$. linum ATCC 11336 determined in this study were deposited in the GenBank data base under accession numbers M26631, M59152, M26630, M26629, M34133, and M22365, respectively.

\section{RESULTS AND DISCUSSION}

In this paper we describe the isolation and characterization of a new type of moderately halophilic eubacterium which has phenotypic and phylogenetic characteristics different from the characteristics of the moderately halophilic gram-negative rods previously described.

Cellular and colonial morphology. The isolate is a gramnegative rod-shaped eubacterium that is 2 by $0.8 \mu \mathrm{m}$. It is characteristically found singly or in pairs. Cells are actively motile by means of a single polar flagellum (Fig. 1).

Colonies on complex or defined media containing $2.6 \mathrm{M}$ $\mathrm{NaCl}$ are circular, convex, smooth with entire margins, 0.5 $\mathrm{mm}$ in diameter, and nonpigmented.

Cultural and physiological characterization. Arhodomonas aquaeolei was an obligate halophile that grew in medium containing 1.0 to $3.4 \mathrm{M} \mathrm{NaCl}$. Optimal growth occurred in medium containing about $2.5 \mathrm{M} \mathrm{NaCl}$. Strain $\mathrm{HA}-1^{\mathrm{T}}$ had a specific requirement for $\mathrm{NaCl}$. Salts of $\mathrm{K}^{+}, \mathrm{Mg}^{2+}, \mathrm{Li}^{+}$, or $\mathrm{NH}_{4}{ }^{+}$did not support growth. The chloride anion could not be replaced by $\mathrm{Br}^{-}, \mathrm{NO}_{3}{ }^{-}, \mathrm{SO}_{4}{ }^{2-}$, or $\mathrm{S}_{2} \mathrm{O}_{3}{ }^{2-}$. Growth was not stimulated by increased levels of $\mathrm{Mg}^{2+}, \mathrm{Ca}^{2+}$, or $\mathbf{K}^{+}$. The salt requirement of this organism reflects the conditions in the natural environment from which it was isolated $(6,19)$.

Nitrogen could be supplied as ammonium, nitrate, or tryptone. Glutamic acid and glutamine could serve as sole carbon, nitrogen, and energy sources.

Growth was aerobic. Catalase and oxidase activities were produced. The optimum growth temperature was $37^{\circ} \mathrm{C}$. The temperature range for growth was 20 to $45^{\circ} \mathrm{C}$. The $\mathrm{pH}$ range for growth was 6.0 to 8.0 , with an optimum $\mathrm{pH}$ of 6.5 to 7.5 . Strain HA-1 ${ }^{\mathrm{T}}$ primarily metabolized organic acids (Table 1 ). The biotin requirement of strain $\mathrm{HA}-\mathrm{1}^{\mathrm{T}}$ was determined in basal medium by performing at least six consecutive transfers in medium containing only biotin. Growth was stimulated by yeast extract. Biochemical characteristics are listed below in the description of the species. 


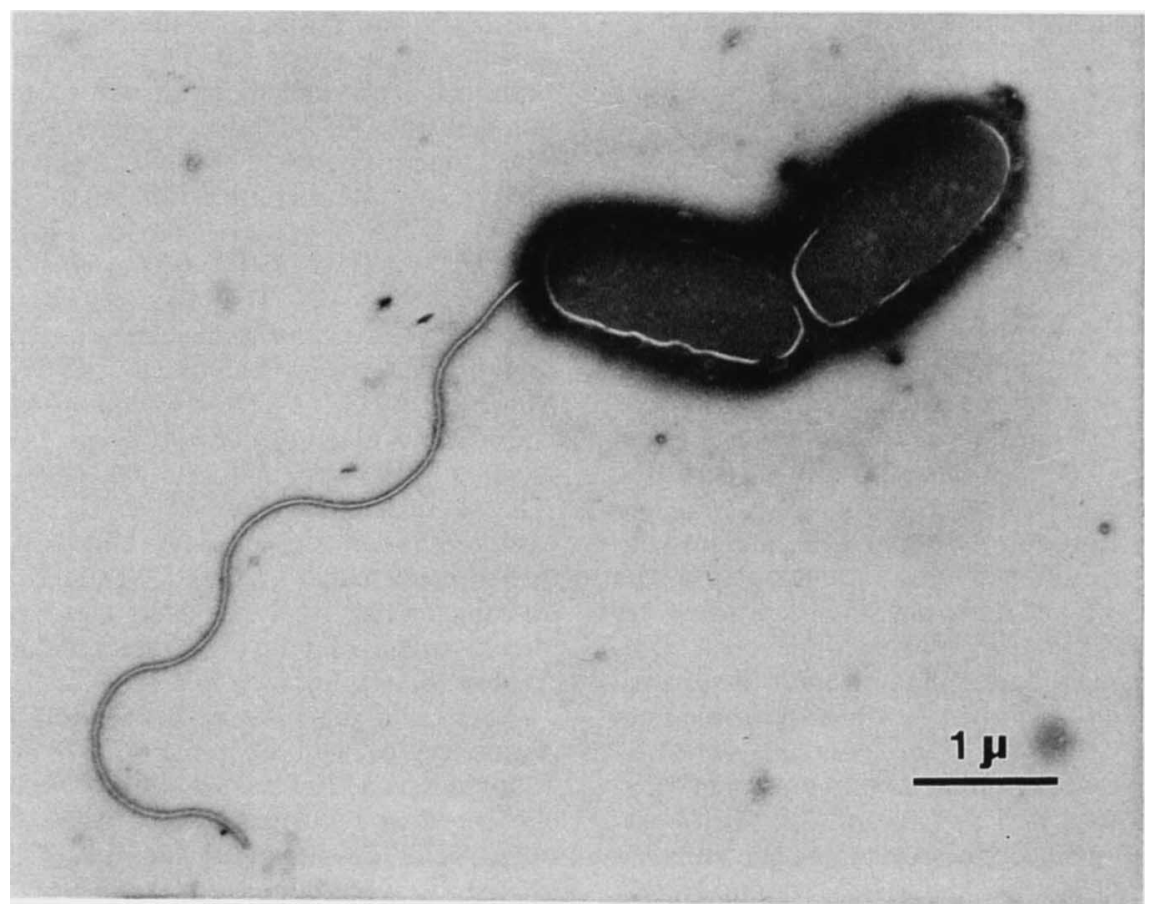

FIG. 1. Transmission electron micrograph of Arhodomonas aquaeolei.

TABLE 1. Utilization of organic carbon sources by Arhodomonas aquaeolei $\mathrm{HA}-1^{\mathrm{T}}$

\begin{tabular}{|c|c|}
\hline Compound ${ }^{a}$ & $\begin{array}{c}\text { Utilization by } \\
\text { Arhodomonas aquaeole } i\end{array}$ \\
\hline Acetate. & $+^{b}$ \\
\hline (................................. & + \\
\hline 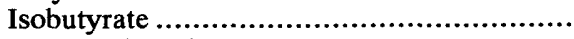 & - \\
\hline 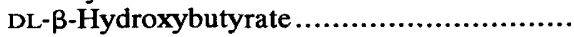 & + \\
\hline 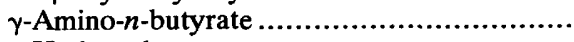 & + \\
\hline$\gamma$-Hydroxybutyrate...................... & - \\
\hline 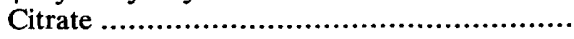 & - \\
\hline 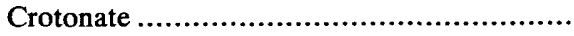 & + \\
\hline 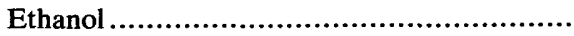 & + \\
\hline 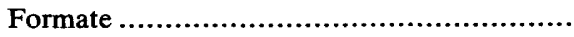 & - \\
\hline 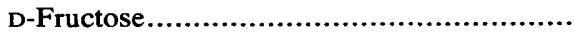 & - \\
\hline 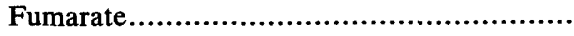 & + \\
\hline 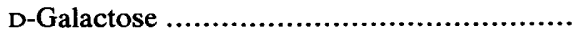 & - \\
\hline D-Gluconate ..................................... & + \\
\hline 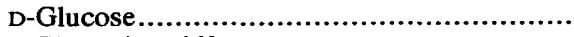 & - \\
\hline 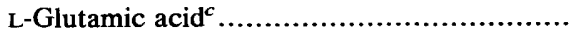 & + \\
\hline 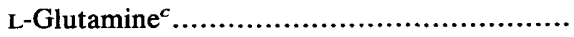 & + \\
\hline 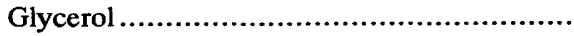 & + \\
\hline 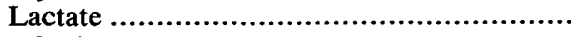 & + \\
\hline D-Malate ......................................... & - \\
\hline 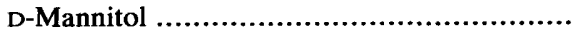 & - \\
\hline Methanol........................................... & - \\
\hline 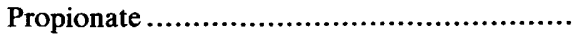 & + \\
\hline 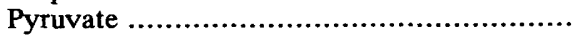 & + \\
\hline 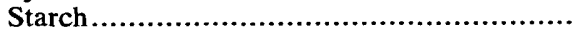 & - \\
\hline 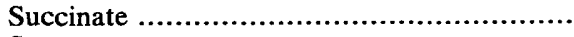 & + \\
\hline 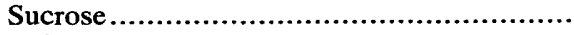 & - \\
\hline 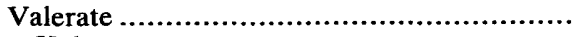 & + \\
\hline 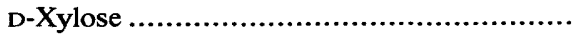 & + \\
\hline
\end{tabular}

$a$ When supplied as the sole source of carbon and energy.
$b+$, positive; - , negative.

${ }^{c}$ When supplied as the sole source of carbon, nitrogen, and energy.
Since the results of the phylogenetic analysis (see below) suggests that there is a relationship between Arhodomonas aquaeolei and the anoxic phototrophic purple sulfur bacterial genera Ectothiorhodospira and Chromatium, attempts were made to culture Arhodomonas aquaeolei phototrophically $(15,31)$. No difference in the growth of Arhodomonas aquaeolei was observed in aerobic phototrophic growth test medium incubated with illumination compared with cultures grown in the dark. No growth of Arhodomonas aquaeolei was observed in anaerobic phototrophic growth test medium when sulfide $(1 \mathrm{mM})$ and thiosulfate $(5 \mathrm{mM})$ were tested as photosynthetic electron donors. Phototrophic growth test medium (without added $\mathrm{NaCl}$ ) supported growth of Chromatium vinosum ATCC 17899 and environmental enrichment cultures of anoxic phototrophic Chromatium species. Although Arhodomonas aquaeolei is most closely related to purple sulfur bacteria (the genera Ectothiorhodospira and Chromatium), it is not a phototrophic microorganism, which is consistent with its isolation from a subterranean environment.

Like Arhodomonas aquaeolei, a specific requirement for sodium exists in all Ectothiorhodospira species (16); however, growth of Ectothiorhodospira mobilis occurs in the absence of added chloride (14). Although all Ectothiorhodospira species grow well under anaerobic conditions in the light, Ectothiorhodospira mobilis and Ectothiorhodospira shaposhnikovii can grow microaerobically in the dark (15). Both Arhodomonas aquaeolei and Ectothiorhodospira species utilize a small number of simple organic compounds, such as certain fatty acids (15).

DNA base composition. The DNA base composition of Arhodomonas aquaeolei was $67.0 \mathrm{~mol} \% \mathrm{G}+\mathrm{C}$.

Phylogeny. A matrix of sequence dissimilarity values for Arhodomonas aquaeolei and selected reference organisms belonging to the gamma subclass of the Proteobacteria is shown in Table 2 . The results of the 16S rRNA sequence 
TABLE 2. Dissimilarity matrix derived from comparisons of $16 \mathrm{~S}$ rRNA sequences of various species in the gamma subclass of the Proteobacteria

\begin{tabular}{|c|c|c|c|c|c|c|c|c|}
\hline \multirow[b]{2}{*}{ Organism } & \multicolumn{8}{|c|}{$\%$ Dissimilarity to ${ }^{a}:$} \\
\hline & $\begin{array}{c}\text { Arhodomonas } \\
\text { aquaeolei }\end{array}$ & $\begin{array}{l}\text { Ectothiorhodospira } \\
\text { halochloris }\end{array}$ & $\begin{array}{l}\text { Ectothiorhodospira } \\
\text { halophila }\end{array}$ & $\begin{array}{c}\text { Chromatium } \\
\text { vinosum }\end{array}$ & $\begin{array}{l}\text { Pseudomonas } \\
\text { aeruginosa }\end{array}$ & $\underset{\text { linum }}{O .}$ & $\begin{array}{l}\text { Escherichia } \\
\quad \text { coli }\end{array}$ & $\begin{array}{l}\text { Proteus } \\
\text { vulgaris }\end{array}$ \\
\hline Ectothiorhodospira halochloris & 9.5 & & & & & & & \\
\hline Ectothiorhodospira halophila & 8.0 & 3.6 & & & & & & \\
\hline Chromatium vinosum & 10.0 & 12.1 & 11.6 & & & & & \\
\hline Pseudomonas aeruginosa & 13.2 & 13.1 & 13.0 & 12.5 & & & & \\
\hline Oceanospirillum linum & 12.5 & 14.2 & 13.6 & 13.1 & 9.9 & & & \\
\hline Escherichia coli & 16.5 & 17.8 & 18.4 & 14.8 & 14.7 & 14.2 & & \\
\hline Proteus vulgaris & 17.9 & 17.5 & 18.2 & 16.6 & 15.9 & 13.9 & 6.3 & \\
\hline Agrobacterium tumefaciens ${ }^{b}$ & 19.3 & 18.2 & 18.1 & 19.0 & 21.9 & 20.4 & 24.4 & 23.8 \\
\hline
\end{tabular}

a Percentages of dissimilarity were estimated from the number of changes per 100 nucleotides. The sequences used were obtained from the Ribosomal Database Project collection $(28,29)$. The strain designations and GenBank accession numbers are given in the text.

${ }^{b}$ Member of the alpha subclass of the Proteobacteria.

analysis (Fig. 2) show that Arhodomonas aquaeolei represents a deeply branching lineage in the gamma subclass of the Proteobacteria of the eubacterial kingdom $(38,47,48)$. Agrobacterium tumefaciens was included as an outgroup reference organism and is a species in the alpha subclass of the Proteobacteria $(38,47,49)$. The results of the $16 \mathrm{~S}$ rRNA sequence analysis indicate that the genus Arhodomonas is a separate genus specifically related to the genus Ectothiorhodospira (15). Arhodomonas aquaeolei does not grow phototrophically. The $16 \mathrm{~S}$ rRNA of Arhodomonas aquaeole $i$ has structural features that link it strongly to the gamma subclass and separate it from members of the alpha, beta, and delta subclasses. The 16S rRNA of Arhodomonas aquaeolei has structural similarities with the 16S rRNAs of the purple sulfur bacteria. The loop starting at position 420 (Escherichia coli numbering) is UGCG in Arhodomonas aquaeolei and species of the genus Ectothiorhodospira, a composition not

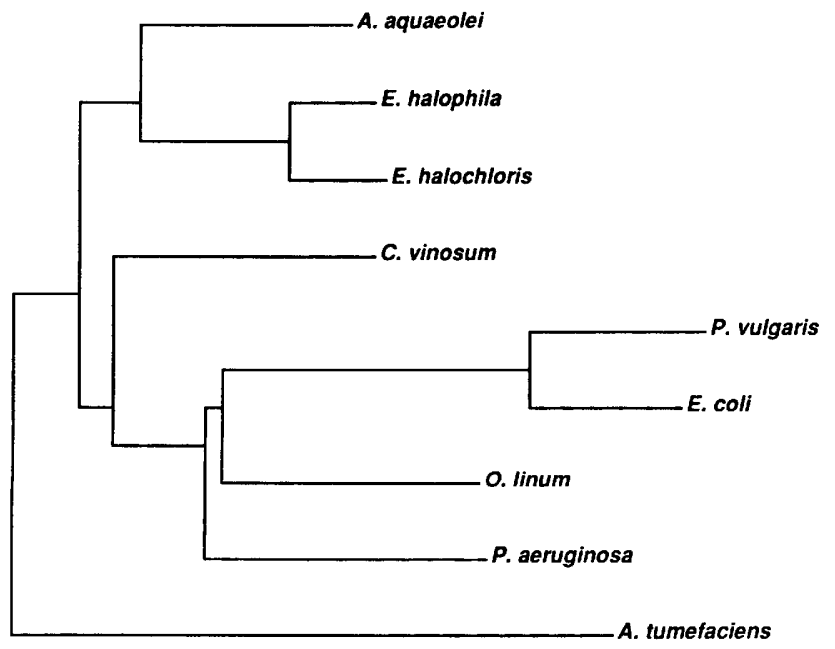

$5 \%$

FIG. 2. Phylogeny of Arhodomonas aquaeolei as determined by a I6S rRNA sequence analysis. The total horizontal distance between two species indicates the level of difference between their sequences. Bar $=5 \%$ difference. Genus names are given in the text. found in other members of the gamma subclass except Chromatium species. The base $\mathrm{C}$ is added in the loop covering position 1361 in Arhodomonas aquaeolei and members of the genus Ectothiorhodospira; this feature is not found in other species of the gamma subclass of the Proteobacteria.

The taxonomy of moderately halophilic, gram-negative, aerobic or facultatively anaerobic, rod-shaped eubacteria has been studied in some detail $(41,44)$. The following species have been validly published: Vibrio costicola (12), Chromohalobacter marismortui (42), Deleya halophila (34), Deleya salina (40), Halomonas elongata (46), Halomonas halmophila (9), Mesophilobacter marinus (27), and Volcaniella eurihalina (33). The family Halomonadaceae, which includes members of the genera Halomonas and Deleya, constitutes an individual subline of descent within the gamma subclass of the Proteobacteria as determined by $16 \mathrm{~S}$ rRNA cataloging (11). The phylogenetic position of Vibrio costicola within the family Vibrionaceae, as determined by 16S rRNA sequence analysis, has recently been reported (18). The phylogenetic positions of Chromohalobacter marismortui, Mesophilobacter marinus, and Volcaniella eurihalina based on 16S rRNA analysis data have not been reported.

Recently, a new species of halophilic eubacteria belonging to the gamma subclass of the Proteobacteria, Marinobacter hydrocarbonoclasticus, was described (13). The genera Marinobacter and Arhodomonas are not related, as indicated by the $\mathrm{G}+\mathrm{C}$ content of Marinobacter hydrocarbonoclasticus (52.7 mol\%) and 16S rRNA sequence analysis data (13). Although Arhodomonas aquaeolei and Marinobacter hydrocarbonoclasticus have similar phenotypic characteristics, they can be differentiated by the following tests: optimal $\mathrm{NaCl}$ concentration, lecithinase activity, and tetracycline and streptomycin susceptibility.

Arhodomonas aquaeolei can be easily differentiated from Mesophilobacter marinus since Mesophilobacter marinus is a nonmotile coccobacillus, grows on glucose and sucrose, and has a G+C content of 44.0 to $46.9 \mathrm{~mol} \%$ (27). Useful characteristics for distinguishing Arhodomonas aquaeolei from other moderately halophilic, aerobic, heterotrophic, gram-negative, rod-shaped bacteria are shown in Table 3.

Since there are significant phenotypic and phylogenetic differences between our isolate (strain HA-1 ${ }^{\mathrm{T}}$ ) and the previously described moderately halophilic bacteria, we propose a new genus, Arhodomonas, and a new species, Arhodomonas aquaeolei, for this organism. 
TABLE 3. Differential characteristics for Arhodomonas aquaeolei HA-1 ${ }^{\mathrm{T}}$ (= ATCC $49307^{\mathrm{T}}$ ) and other aerobic, moderately halophilic, gram-negative, rod-shaped eubacteria ${ }^{a}$

\begin{tabular}{|c|c|c|c|c|c|c|c|}
\hline \multirow{2}{*}{ Strain } & \multirow{2}{*}{$\begin{array}{l}\text { Optimum salt } \\
\text { concn }(\%)\end{array}$} & \multirow{2}{*}{$\begin{array}{l}\text { Oxygen } \\
\text { relationship }\end{array}$} & \multirow{2}{*}{ Motility } & \multirow{2}{*}{$\begin{array}{c}\text { Oxidase } \\
\text { production }\end{array}$} & \multirow{2}{*}{$\begin{array}{l}\text { Nitrate } \\
\text { reduction }\end{array}$} & \multicolumn{2}{|c|}{ Growth on ${ }^{b}$ : } \\
\hline & & & & & & Glucose & Sucrose \\
\hline Arhodomonas aquaeolei ATCC $49307^{\mathrm{T}}$ & $15^{c}$ & Aerobe & + & + & + & - & - \\
\hline Chromohalobacter marismortui ATCC $17056^{\mathrm{T}}$ & $10^{d}$ & Aerobe & + & - & - & + & + \\
\hline Deleya halophila CCM $3662^{\mathrm{T}}$ & $7.5^{d}$ & Aerobe & + & + & + & + & + \\
\hline Deleya salina ATCC $49509^{\mathrm{T}}$ & $5^{d}$ & Aerobe & - & + & + & - & - \\
\hline Halomonas elongata ATCC $33173^{\mathrm{T}}$ & $3.5-8^{c}$ & Facultative anaerobe & + & - & + & + & + \\
\hline Halomonas halmophila CCM $2833^{\mathrm{T}}$ & $10^{c}$ & Aerobe & + & + & - & + & + \\
\hline Vibrio costicola NCMB $701^{\mathrm{T}}$ & $10^{c}$ & Facultative anaerobe & + & + & - & + & + \\
\hline Volcaniella eurihalina ATCC $49336^{\text {T }}$ & $7.5^{d}$ & Aerobe & - & - & + & - & + \\
\hline
\end{tabular}

${ }^{a}$ Data from references $9,12,33,34,40,42$, and 46 and from this study.

$b$ When glucose and sucrose were supplied as sole sources of carbon and energy.

c Optimum $\mathrm{NaCl}$ concentration.

${ }^{d}$ Optimum total-salts concentration.

Description of Arhodomonas gen. nov. Arhodomonas (A rho.do.mo.nas. Gr.pref. $a$, not; Gr. adj. rhodos, red; Gr. n. monas, a unit; M.L. fem. n., Arhodomonas, a non-red cell).

Gram-negative, short, straight, rod-shaped cells occurring singly or in pairs. Motile by means of a single polar flagellum. Not spore forming and not encapsulated.

Respiratory metabolism. Catalase and oxidase positive. Nitrate is reduced. Nitrite is not reduced. Nonphototrophic.

Phylogenetically, the genus Arhodomonas represents a deeply branching lineage in the gamma subclass of the Proteobacteria (as determined by 16S rRNA sequence analysis). The $\mathrm{G}+\mathrm{C}$ content of the DNA of the type strain of the type species is $67 \mathrm{~mol} \%$ (as determined by the thermal denaturation method).

The type species is Arhodomonas aquaeolei.

Description of Arhodomonas aquaeolei sp. nov. Arhodomonas aquaeolei (a.quae.o'le.i. L. n. aqua, water: L. n. oleum, oil; M.L. gen. n. aquaeolei, from water of oil, isolated from an oil field brine).

Growth in liquid cultures is uniformly turbid with a pellicle forming after $72 \mathrm{~h}$ of incubation.

Gram-negative, short, straight, rod-shaped cells that are 0.8 to $1.0 \mu \mathrm{m}$ in diameter and 2.0 to $2.5 \mu \mathrm{m}$ long and occur singly or in pairs. Motile by means of a single polar flagellum. Not spore forming and not encapsulated. Colonies on complex medium containing $2.6 \mathrm{M} \mathrm{NaCl}$ are circular with entire margins, convex, and smooth; they are $0.5 \mathrm{~mm}$ in diameter after $72 \mathrm{~h}$ and nonpigmented.

The optimal $\mathrm{NaCl}$ concentration is $15 \%$; grows in the presence of $\mathrm{NaCl}$ concentrations between 6 to $20 \%$. No growth occurs in the absence of $\mathrm{NaCl}$. Growth occurs at 20 to $45^{\circ} \mathrm{C}$ and $\mathrm{pH} 6$ to 8 ; optimal growth occurs at $37^{\circ} \mathrm{C}$ and $\mathrm{pH}$ 7.

Aerobic. Respiratory metabolism with $\mathrm{O}_{2}$ as the terminal electron acceptor. Catalase and oxidase positive. Nitrate is reduced. Nitrite is not reduced.

Tween 20 and Tween 80 are hydrolyzed. Casein, DNA, esculin, gelatin, starch, and tyrosine are not hydrolyzed. Urease is produced. Negative for arginine, lysine, and ornithine decarboxylase activities. The following tests are negative: Simmons citrate, methyl red, Voges-Proskauer, indole, lecithinase, $\mathrm{H}_{2} \mathrm{~S}$ production, phenylalanine deaminase, and phosphatase. Cells are susceptible to ampicillin (10 $\mu \mathrm{g})$, carbenicillin $(100 \mu \mathrm{g})$, chloramphenicol $(30 \mu \mathrm{g})$, erythromycin $(15 \mu \mathrm{g})$, penicillin $\mathrm{G}(10 \mathrm{U})$, and tetracycline (30 $\mu \mathrm{g})$. Cells are resistant to gentamicin $(10 \mu \mathrm{g})$, neomycin (30 $\mu \mathrm{g})$, streptomycin $(10 \mu \mathrm{g})$, and vancomycin $(30 \mu \mathrm{g})$.
The following compounds are utilized as sole carbon and energy sources: acetate, butyrate, crotonate, ethanol, fumarate, gluconate, glycerol, lactate, propionate, pyruvate, succinate, valerate, isovalerate, xylose, yeast extract, and Casamino Acids. Acids are not produced from these compounds.

The following compounds are not utilized as sole carbon and energy sources: adonitol, allantoin, arabinose, benzoate, betaine, butanol, cellobiose, citrate, esculin, formate, fructose, fucose, galactose, glucose, glucosamine, glycolate, heptanoate, hexanoate, hippurate, inulin, inositol, isopropanol, lactose, malate, maleate, malonate, maltose, mannitol, mannose, melezitose, methanol, propanol, oxamate, raffinose, rhamnose, ribose, saccharose, salicin, sorbose, starch, sucrose, tartarate, trehalose, turanose, and xylitol.

Glutamic acid and glutamine are used as sole carbon, nitrogen, and energy sources. The other common amino acids do not support growth.

The major components of the cellular fatty acids are $\mathrm{C}_{16: 0}$ acid $(21.74 \%), \mathrm{C}_{18: 1}$ acid $(21.74 \%), \mathrm{C}_{19: 0}$ acid $(12.72 \%), \mathrm{C}_{16: 1}$ acid $(12.55 \%)$, and $\mathrm{C}_{18: 0}$ acid (11.20\%).

The $\mathrm{G}+\mathrm{C}$ content of the DNA is $67 \mathrm{~mol} \%$ (as determined by the thermal denaturation method).

The type and only strain is Arhodomonas aquaeolei HA-1, which was isolated from a petroleum reservoir production fluid; it has been deposited in the American Type Culture Collection as strain ATCC 49307.

\section{ACKNOWLEDGMENTS}

We thank Woody Jenkins, who originally isolated Arhodomonas aquaeolei, David P. Nagle, Jr., for his assistance in determining the $\mathrm{G}+\mathrm{C}$ content, and the staff of the Samuel Roberts Noble Electron Microscopy Laboratory for assistance with the electron microscopy.

Part of this work was supported by grant BSR-87-05352 from the National Science Foundation (to C. R. Woese).

\section{REFERENCES}

1. Adkins, J. P., L. A. Cornell, and R. S. Tanner. 1992. Microbial composition of carbonate petroleum reservoir fluids. Geomicrobiol. J. 10:87-97.

2. Adkins, J. P., M. T. Madigan, L. Mandelco, C. R. Woese, and R. S. Tanner. 1990. Arhodomonas oleiferhydrans HA-1 gen. nov., sp. nov., a new aerobic, obligately halophilic bacterium isolated from subterranean brine, abstr. R-12, p. 247. Abstr. 90th Annu. Meet. Am. Soc. Microbiol. 1990.

3. Balch, W. E., G. E. Fox, L. J. Magrum, C. R. Woese, and R. S. Wolfe. 1979. Methanogens: reevaluation of a unique biological 
group. Microbiol. Rev. 43:260-296.

4. Balch, W. E., and R. S. Wolfe. 1976. New approach to the cultivation of methanogenic bacteria: 2-mercaptoethanesulfonic acid (HS-CoM)-dependent growth of Methanobacterium ruminantium in a pressurized atmosphere. Appl. Environ. Microbiol. 32:781-791.

5. Bejar, V., E. Quesada, M. C. Guitierrez, A. Del Moral, M. J. Valderrama, A. Ventosa, F. Ruiz-Berraquero, and A. RamosCormenzana. 1992. Taxonomic study of moderately halophilic gram-positive endospore-forming rods. Syst. Appl. Microbiol. 14:223-228.

6. Bhupathiraju, V. K., P. K. Sharma, M. J. McInerney, R. M. Knapp, K. Fowler, and W. Jenkins. 1991. Isolation and characterization of novel halophilic anaerobic bacteria from oil field brines. Dev. Petrol. Sci. 31:131-143.

7. Brosius, J., M. L. Palmer, P. J. Kennedy, and H. F. Noller. 1978. Complete nucleotide sequence of a 16S ribosomal RNA gene from Escherichia coli. Proc. Natl. Acad. Sci. USA 75:48014805.

8. DeSoete, G. 1983. A least square algorithm for fitting additive trees to proximity data. Psychometrika 48:621-626.

9. Dobson, S. J., S. R. James, P. D. Franzmann, and T. A. McMeekin. 1990. Emended description of Halomonas halmophila (NCMB 1971 ${ }^{\mathrm{T}}$ ). Int. J. Syst. Bacteriol. 40:462-463.

10. Dobson, S. J., S. R. James, P. D. Franzmann, and T. A. McMeekin. 1991. A numerical taxonomic study of some pigmented bacteria isolated from Organic Lake, an antarctic hypersaline lake. Arch. Microbiol. 156:56-61.

11. Franzmann, P. D., U. Wehmeyer, and E. Stackebrandt. 1988. Halomonadaceae fam. nov., a new family of the class Proteobacteria to accommodate the genera Halomonas and Deleya. Syst. Appl. Microbiol. 11:16-19.

12. Garcia, M. T., A. Ventosa, F. Ruiz-Berraquero, and M. Kocur. 1987. Taxonomic study and amended description of Vibrio costicola. Int. J. Syst. Bacteriol. 37:251-256.

13. Gauthier, M. J., B. Lafay, R. Christen, L. Fernandez, M. Acquaviva, P. Bonin, and J. C. Bertrand. 1992. Marinobacter hydrocarbonoclasticus gen. nov., sp. nov., a new, extremely halotolerant, hydrocarbon-degrading marine bacterium. Int. J. Syst. Bacteriol. 42:568-576.

14. Imhoff, J., and T. Riedel. 1989. Requirements for, and cytoplasmic concentrations of, sulphate and chloride, and cytoplasmic volume spaces in the halophilic bacterium Ectothiorhodospira mobilis. J. Gen. Microbiol. 135:237-244.

15. Imhoff, J. F. 1992. The family Ectothiorhodospiraceae, p. 3223-3229. In A. Balows, H. G. Trüper, M. Dworkin, W. Harder, and K. H. Schleifer (ed.), The prokaryotes, vol. 4, 2nd ed. Springer-Verlag, New York.

16. Imhoff, J. F., T. Ditandy, and B. Thiemann. 1991. Salt adaption of Ectothiorhodospira, p. 115-120. In F. Rodriguez-Valera (ed.), General and applied aspects of halophilic microorganisms. Plenum Press, New York.

17. Jukes, T. H., and C. R. Cantor. 1969. Evolution of protein molecules, p. 21-132. In H. N. Munro (ed.), Mammalian protein metabolism, vol. 3. Academic Press, New York.

18. Kita-Tsukamoto, K., H. Oyaizu, K. Nanba, and U. Simidu. 1993. Phylogenetic relationships of marine bacteria, mainly members of the family Vibrionaceae, determined on the basis of $16 \mathrm{~S}$ rRNA sequences. Int. J. Syst. Bacteriol. 43:8-19.

19. Knapp, R. M., J. L. Chisolm, M. J. McInerney, and D. E. Menzie. 1989. Pre-test studies and design for a microbially enhanced oil recovery field pilot, p. 48-58. In Proceedings of the Eighth Tertiary Oil Recovery Conference. University of Kansas, Lawrence.

20. Kushner, D. J., and M. Kamekura. 1988. Physiology of halophilic eubacteria, p. 109-138. In F. Rodriquez-Valera (ed.), Halophilic bacteria, vol. 1. CRC Press, Inc., Boca Raton, Fla.

21. Lane, D. J., B. Pace, G. J. Olsen, D. A. Stahl, M. L. Sogin, and N. R. Pace. 1985. Rapid determination of 16 S ribosomal RNA sequences for phylogenetic analysis. Proc. Natl. Acad. Sci. USA 82:6955-6959.

22. Marmur, J. 1961. A procedure for the isolation of deoxyribonucleic acid from micro-organisms. J. Mol. Biol. 3:208-218.
23. Marmur, J., and P. Doty. 1962. Determination of the base composition of deoxyribonucleic acid from its thermal denaturation temperature. J. Mol. Biol. 5:109-118.

24. Miller, L. T. 1982. Single derivitization method for routine analysis of bacterial whole-cell fatty acid methyl esters, including hydroxy acids. J. Clin. Microbiol. 16:584-586.

25. Moss, C. W., P. L. Wallace, D. G. Hollis, and R. E. Weaver. 1988. Cultural and chemical characterization of CDC groups EO-2, M-5, and M-6, Moraxella (Moraxella) species, Oligella urethralis, Acinetobacter species, and Psychrobacter immobilis. J. Clin. Microbiol. 26:484-492.

26. Neefs, J. M., Y. Van der Peer, L. Hendriks, and R. De Wachter. 1990. Compilation of small ribosomal subunit RNA sequences. Nucleic Acids Res. 18:2237-2317.

27. Nishimura, Y., M. Kinpara, and H. Iizuka. 1989. Mesophilobacter marinus gen. nov., sp. nov.: an aerobic coccobacillus isolated from seawater. Int. J. Syst. Bacteriol. 39:378-381.

28. Olsen, G. J., N. Larsen, and C. R. Woese. 1991. The ribosomal RNA database project. Nucleic Acids Res. 19:2017-2021.

29. Olsen, G. J., R. Overbeek, N. Larsen, T. L. Marsh, M. J. McCaughey, M. A. Maciukenas, W. M. Kuan, T. J. Macke, Y. Xing, and C. R. Woese. 1992. The ribosomal database project. Nucleic Acids Res. 20:2199-2200.

30. Oyaizu, H., B. Debrunner-Vossbrinck, L. Mandelco, J. A. Studier, and C. R. Woese. 1987. The green non-sulfur bacteria: a deep branching in the eubacterial line of descent. Syst. Appl. Microbiol. 9:47-53.

31. Pfennig, N., and H. G. Trüper. 1992. The family Chromatiaceae, p. 3200-3221. In A. Balows, H. G. Trüper, M. Dworkin, W. Harder, and K. H. Schleifer (ed.), The prokaryotes, vol. 4, 2nd ed. Springer-Verlag, New York.

32. Prado, B., A. Del Moral, E. Quesada, R. Rios, M. MonteolivaSanchez, V. Campos, and A. Ramos-Cormenzana. 1991. Numerical taxonomy of moderately halophilic gram-negative rods isolated from the Salar de Atacama, Chile. Syst. Appl. Microbiol. 14:275-281.

33. Quesada, E., M. J. Valderrama, V. Bejar, A. Ventosa, M. C. Gutierrez, F. Ruiz-Berraquero, and A. Ramos-Cormenzana. 1990. Volcaniella eurihalina gen. nov., sp. nov., a moderately halophilic nonmotile gram-negative rod. Int. J. Syst. Bacteriol. 40:261-267.

34. Quesada, E., A. Ventosa, F. Ruiz-Berraquero, and A. RamosCormenzana. 1984. Deleya halophila, a new species of moderately halophilic bacteria. Int. J. Syst. Bacteriol. 34:287-292.

35. Rodriguez-Valera, F. (ed.). 1991. General and applied aspects of halophilic microorganisms. Plenum Press, New York.

36. Sasser, M. 1990. Identification of bacteria by gas chromatography of cellular fatty acids. MIDI Technical Note 101. MIDI, Inc., Newark, Del.

37. Smibert, R. M., and N. R. Krieg. 1981. General characterization, p. 409-443. In P. Gerhardt, R. G. E. Murray, R. N. Costilow, E. W. Nester, W. A. Wood, N. R. Krieg, and G. B. Phillips (ed.), Manual of methods for general bacteriology. American Society for Microbiology, Washington, D.C.

38. Stackebrandt, E., R. G. E. Murray, and H. G. Trüper. 1988. Proteobacteria classis nov., a name for the phylogenetic taxon that includes the "purple bacteria and their relatives." Int. J. Syst. Bacteriol. 38:321-325.

39. Tanner, R. S. 1989. Monitoring sulfate-reducing bacteria: comparison of enumeration media. J. Microbiol. Methods 10:83-90.

40. Valderrama, M. J., E. Quesada, V. Bejar, A. Ventosa, M. C. Gutierrez, F. Ruiz-Berraquero, and A. Ramos-Cormenzana. 1991. Deleya salina sp. nov., a moderately halophilic gramnegative bacterium. Int. J. Syst. Bacteriol. 41:377-384.

41. Ventosa, A. 1988. Taxonomy of moderately halophilic heterotrophic eubacteria, p. 71-84. In F. Rodriguez-Valera (ed.), Halophilic bacteria, vol. 1. CRC Press, Inc., Boca Raton, Fla.

42. Ventosa, A., M. C. Gutierrez, M. T. Garcia, and F. RuizBerraquero. 1989. Classification of "Chromohalobacterium marismortui"' in a new genus, Chromohalobacter gen. nov., as Chromohalobacter marismortui comb. nov., nom. rev. Int. J. Syst. Bacteriol. 39:382-386.

43. Ventosa, A., E. Quesada, F. Rodriguez-Valera, F. Ruiz-Ber- 
raquero, and A. Ramos-Cormenzana. 1982. Numerical taxonomy of moderately halophilic gram-negative rods. J. Gen. Microbiol. 128:1959-1968.

44. Vreeland, R. H. 1993. Taxonomy of halophilic bacteria, p. 105-134. In R. H. Vreeland and L. 1. Hochstein (ed.), The biology of halophilic bacteria. CRC Press, Inc., Boca Raton, Fla.

45. Vreeland, R. H., and L. I. Hochstein (ed.). 1993. The biology of halophilic bacteria. CRC Press, Inc., Boca Raton, Fla.

46. Vreeland, R. H., C. D. Litchfield, E. L. Martin, and E. Elliot. 1980. Halomonas elongata, a new genus and species of ex- tremely salt-tolerant bacteria. Int. J. Syst. Bacteriol. 30:485495.

47. Woese, C. R. 1987. Bacterial evolution. Microbiol. Rev. 51:221271.

48. Woese, C. R., W. G. Weisburg, C. M. Hahn, B. J. Paster, L. B. Zablen, B. J. Lewis, T. J. Macke, W. Ludwig, and E. Stackebrandt. 1985. The phylogeny of the purple bacteria: the gamma subdivision. Syst. Appl. Microbiol. 6:25-33.

49. Yang, D., H. Oyaizu, Y. Oyaizu, G. J. Olsen, and C. R. Woese. 1985. Mitochondrial origins. Proc. Natl. Acad. Sci. USA 82: $4443-4447$. 